\title{
PENGARUH PELATIHAN KERJA DAN PENGALAMAN KERJA TERHADAP KINERJA KARYAWAN PADA PT. ISS INDONESIA
}

\author{
Prasetyo Kurniawan ${ }^{1}$, Noto Susanto ${ }^{2}$ \\ Fakultas Ekonomi, Universitas Pamulang \\ Email: dosen02261@unpam.ac.id ${ }^{1}$, dosen02580@unpam.ac.id ${ }^{2}$
}

\begin{abstract}
Destination. This study was conducted to determine the effect of job training and work experience on employee performance at PT. ISS Indonesia.

Method. The method used in this study using the Associative method. The sample used in this study was 150 respondents. Data collection techniques in this study using a questionnaire. The data analysis techniques in this study used descriptive statistics, validity and reliability tests, classical assumption tests, and partial and simultaneous hypothesis testing.

Results. The results showed that: 1) There was a positive and significant effect of job training on employee performance at PT. ISS Indonesia. 2) There is a positive and significant effect of work experience on employee performance at PT. ISS Indonesia. 3) There is a positive and significant effect of job training and work experience simultaneously on employee performance at PT. ISS Indonesia.
\end{abstract}

Implications. To improve the performance of employees, the company needs to pay attention to the knowledge and skills of employees by holding regular training.

Keywords: Job Training, Work Experience, Employee Performance

\section{ABSTRAK}

Tujuan. Penelitian ini dilakukan untuk mengetahui Pengaruh pelatihan kerja dan pengalaman kerja terhadap kinerja karyawan pada PT. ISS Indonesia.

Metode. Metode yang digunakan dalam penelitian ini menggunakan metode Asosiatif. Sampel yang digunakan dalam penelitian ini sebanyak 150 responden. Teknik pengumpulan data dalam penelitian ini menggunakan kuesioner. Adapun teknik analisis data dalam penelitian ini menggunakan, statistik deskriptif, uji validitas dan reliabilitas, uji asumsi klasik dan pengujian hipotesis parsial serta simultan.

Hasil. Hasil penelitian menunjukan bahwa: 1) Terdapat pengaruh positif dan signifikan pelatihan kerja terhadap kinerja karyawan pada PT. ISS Indonesia. 2) Terdapat pengaruh positif dan signifikan pengalaman kerja terhadap kinerja karyawan pada PT. ISS Indonesia. 3) Terdapat pengaruh positif dan signifikan pelatihan kerja dan pengalaman kerja secara simultan terhadap kinerja karyawan pada PT. ISS Indonesia.

Implikasi. Untuk meningkatkan kinerja karyawan perusahaan perlu memperhatikan pengetahuan dan keterampilan karyawan dengan mengadakan pelatihan secara berkala.

Kata Kunci : Pelatihan Kerja, Pengalaman Kerja, Kinerja Karyawan 


\section{Pendahuluan}

PT. ISS adalah suatu perusahaan yang bergerak dalam bidang fasilitas pelayanan yang terbesar di dunia fasilitas pelayanan. Didirikan di Jakarta, PT. ISS Indonesia kini telah menjadi pembersihan terkemuka dan fasilitas perusahaan jasa, yang berjumlah lebih dari 2000 pelanggan dan lebih dari 50.000 karyawan saat ini. PT. ISS berusaha untuk mengembangkan dan memelihara lingkungan yang berkelanjutan dan terlihat untuk memimpin industri dengan menetapkan standar uji praktek terbaik dan mempertahankan kinerja unggul. PT. ISS juga berinvestasi dalam inovasi produk dan layanan yang berfokus pada teknologi dan sistem yang menggunakan sumber daya keuangan, alam, dan sosial secara efisien, efektif, dan ekonomis dalam jangka panjang.

Kinerja merupakan hasil kerja yang dicapai oleh seorang pegawai dalam melaksanakan tugas-tugas yang dibebankan kepadanya sesuai dengan tanggung jawab yang diberikan kepadanya, yang didasarkan pada kecakapan, pengalaman dan keunggulan serta waktu dengan output yang dihasilkan tercermin dengan baik. Kinerja juga merupakan suatu pencapaian persyaratan pekerjaan tertentu yang akhirnya secara langsung dapat tercermin dari output yang dihasilkan baik kuantitas maupun kualitas.

Fenomena yang terjadi pada PT. ISS adalah karyawan dengan pengalaman kerja yang lama, karyawan senior, sering kurang mau mengikuti pelatihan, karena merasa sudah mampu menyelesaikan pekerjaan yang menjadi tanggungjawabnya, dan karena sudah dianggap menjadi kebiasaan sehingga akan mengurangi kinerja perusahaan secara umum. Berdasarkan hasil observasi dengan salah satu pihak peserta pelatihan maka dapat diidentifikasikan beberapa masalah yang sering membuat peserta tidak puas dengan metode pelatihan kerja yang telah dilaksanakan.

Pelatihan perlu memperhatikan antara lain kesesuaian materi dengan kebutuhan pelatihan, kualitas pelatih dan instruktur, kualitas peserta, kelengkapan sarana dan prasarana yang sesuai dalam melaksanakan kegiatan pelatihan serta penyediaan biaya. Apabila aspek aspek tersebut dapat dipenuhi dengan baik maka pelatihan yang dilaksanakan akan mempunyai pengaruh terhadap kinerja pegawai. Pelatihan akan menentukan kinerja karyawan, sedangkan kinerja akan meningkat apabila dilakukan pelatihan dengan persyaratan yang baik.

Pada kesempatan berbeda dilakukan wawancara dengan narasumber yang berbeda pula, mereka mengatakan bahwa keterampilan yang mereka miliki serta pengetahuan akan pekerjaan yang mereka emban ketika diawal bekerja tidaklah memadai, sehingga lagi-lagi kunci utama bagi karyawan untuk menghadapi situasi tersebut adalah dengan banyak bertanya kepada karyawan lain yang lebih mengerti dan memahami kualifikasi pekerjaan tersebut. Kemudian pegawai lainnya menambahkan bahwa kurangnya pengalaman kerja yang dimiliki pegawai dalam melaksanakan pekerjaan yang dibebankan kepada dirinya. Selain itu, pegawai yang bersangkutan mengatakan bahwa masih adanya penempatan kerja yang dilakukan oleh perusahaan dengan mengabaikan pengetahuan, kemampuan serta keterampilan yang dimiliki oleh karyawan. Pelatihan (training) merupakan proses pembelajaran yang melibatkan perolehan keahlian, konsep, peraturan, atau sikap untuk meningkatkan kinerja karyawan.

Tidak hanya pelatihan pengalaman kerja juga perlu diperhatikan dalam meningkatkan kinerja karyawan. Pengalaman karyawan juga berpengaruh terhadap kinerjanya. Masa kerja juga dapat mempengaruhi kualitas kinerja karyawan. Kinerja karyawan yang belum memiliki masa kerja atau pengalaman akan berbeda dengan kinerja karyawan yang sudah memiliki masa kerja cukup banyak. Kondisi yang ada pada PT. ISS Indonesia pada saat ini terlihat bahwa ada beberapa karyawan senior dalam hal ini adalah mereka yang memiliki pengalaman kerja sudah lama dalam arti kata telah bekerja lebih dari 3 tahun memiliki kinerja yang standar, tidak terlalu bagus dan juga tidak terlalu buruk, hal ini dapat dipengaruhi karena posisi mereka pada saat ini sudah mapan dan juga merupakan karyawan tetap. Selain itu dengan pengalaman kerja yang lebih lama, dapat disebut bahwa loyalitas mereka terhadap PT. ISS Indonesia sudah baik, namun yang menjadi perhatian adalah sedikitnya karyawan dengan pengalaman kerja cukup mau mengikuti pelatihan. Sebagain besar karyawan senior memiliki 
anggapan bahwa pelatihan hanya diperlukan bagi karyawan baru dan bukan merupakan bagian dari renacana kerja perusahaan dalam peningkatan kinerja.

Penelitian yang telah dilakukan Hafeez dan Akbar (2015) tentang yang berjudul Impact of Training on Employees Performance (Evidence from Pharmaceutical Companies in Karachi, Pakistan) dengan hasil penelitian menunjukkan pelatihan memiliki dampak yang signifikan dan hubungan positif dengan kinerja karyawan. Selanjutnya, penelitian yang dilakukan oleh Septiani (2015) tentang Pengaruh pelatihan, pengalaman kerja, dan promosi jabatan terhadap kinerja karyawan pada badan pemeriksa keuangan Republik Indonesia perwakilan Sulawesi Utara dengan hasil penelitian menunjukkan Pelatihan dan pengalaman kerja secara parsial dan simultan berpengaruh dan signifikan terhadap kinerja karyawan. Dengan memperhatikan fenomena diatas, dilakukan penelitian tentang Pengaruh Pelatihan Kerja Dan Pengalaman Kerja Terhadap Kinerja Karyawan Pada PT. ISS Indonesia.

\section{Kajian Pustaka dan Hipotesis}

Pelatihan Kerja. Pelatihan adalah usaha untuk meningkatkan prestasi kerja (kinerja) karyawan dalam pekerjaannya sekarang atau dalam pekerjaan lain yang akan dijabatnya segera". Dessler (2015:284), mengemukakan bahwa "Pelatihan merupakan proses mengajarkan pegawai baru atau yang ada sekarang, keterampilan dasar yang mereka butuhkan untuk menjalankan pekerjaan mereka. Pelatihan merupakan salah satu usaha dalam meningkatkan mutu sumber daya manusia dalam dunia kerja. Pegawai baik yang baru atau pun yang sudah bekerja perlu mengikuti pelatihan". Gomes (2016:197) mendefinisikan pelatihan adalah setiap usaha untuk memperbaiki prestasi kerja pada suatu pekerjaan tertentu yang sedang menjadi tanggung jawabnya. Menurut Widodo (2015:82), pelatihan merupakan serangkaian aktivitas individu dalam meningkatkan keahlian dan pengetahuan secara sistematis sehingga mampu memiliki kinerja yang profesional di bidangnya. Pelatihan adalah proses pembelajaran yang memungkinkan pegawai melaksanakan pekerjaan yang sekarang sesuai dengan standar.

Berdasarkan pada pendapat para ahli diatas, maka dapat di simpulkan bahwa pelatihan adalah suatu alat manajemen sumber daya manusia yang digunakan untuk memperoleh keahlian, keterampilan, atau sikap pegawai dalam rangka meningkatkan prestasi kerja pegawai.

Pengalaman Kerja. Menurut Sutrisno (2016:158) "Pengalaman kerja adalah suatu dasar/acuan seorang karyawan dapat menempatkan diri secara tepat kondisi, berani mengambil resiko, mampu menghadapi tantangan dengan penuh tanggung jawab serta mampu berkomunikasi dengan baik terhadap berbagai pihak untuk tetap menjaga produktivitas, kinerja dan menghasilkan individu yang kompeten dalam bidangnya". Menurut Trijoko (2008:82) "Pengalaman kerja adalah pengetahuan atau keterampilan yang telah diketahui dan dikuasai seseorang yang akibat dari perbuatan atau pekerjaan yang telah dilakukan selama beberapa waktu tertentu". Sementara itu Menurut Malayu S.P Hasibuan (2016:55), orang yang berpengalaman merupakan calon karyawan yang telah siap pakai. Pengalaman kerja seorang pelamar hendaknya mendapat pertimbangan utama dalam proses seleksi.

Berdasarkan beberapa pendapat diatas dapat disimpulkan bahwa pengalaman kerja adalah tingkat pengetahuan serta keterampilan seseorang yang dapat diukur dari masa kerja yang pernah dilakukan seseorang. Sehingga semakin lama seseorang bekerja semakin bertambah pengalamannya terhadap pekerjaannya. Banyaknya pengalaman kerja yang dimiliki seseorang pekerja maka orang tersebut akan lebih menguasai pekerjaannya, sehingga dapat menyelesaikan pekerjaannya dengan baik, ini berarti orang tersebut mempunyai efektivitas kerja yang baik. Selain itu, juga pengalaman kerja akan ikut mematangkan orang yang bersangkutan dalam menghadapi tugas-tugas manajerial yang akan dijalankannya. 
Kinerja Karyawan. Menurut Mangkunegara (2016:67), Pengertian kinerja adalah "hasil kerja secara kualitas dan kuantitas yang dicapai oleh seorang pegawai dalam melaksanakan tugasnya sesuai dengan tanggung jawab yang diberikan kepadanya". Menurut Edison (2016:190), "Kinerja adalah hasil dari suatu proses yang mengacu dan diukur selama periode waktu tertentu berdasarkan ketentuan atau kesepakatan yang telah ditetapkan sebelumnya". Sedangkan menurut Hasibuan (2016:138), "kinerja karyawan suatu hasil yang dicapai oleh seseorang dalam melaksanakan tugas-tugas yang dibebankan kepadanya". Menurut Robert dan Bacal (2016:153) "kinerja merupakan tingkat kontribusi yang diberikan pegawai terhadap tujuan pekerjaannya atau unit kerja dan perusahaan/organisasi sebagai hasil perilakunya dan aplikasi dari keterampilan, kemampuan, dan pengetahuannya". Menurut Widodo (2015:131) "kinerja adalah hasil yang dicapai seseorang pada pekerjaan yang bersangkutan sesuai dengan ukuran yang berlaku".

Berdasarkan pendapat para ahli tersebut, definisi kinerja sebagai hasil kerja yang dicapai oleh individu yang disesuaikan dengan peran atau tugas individu tersebut dalam suatu organisasi yang dihubungkan dengan suatu ukuran nilai atau standar tertentu dari organisasi dimana individu bekerja.

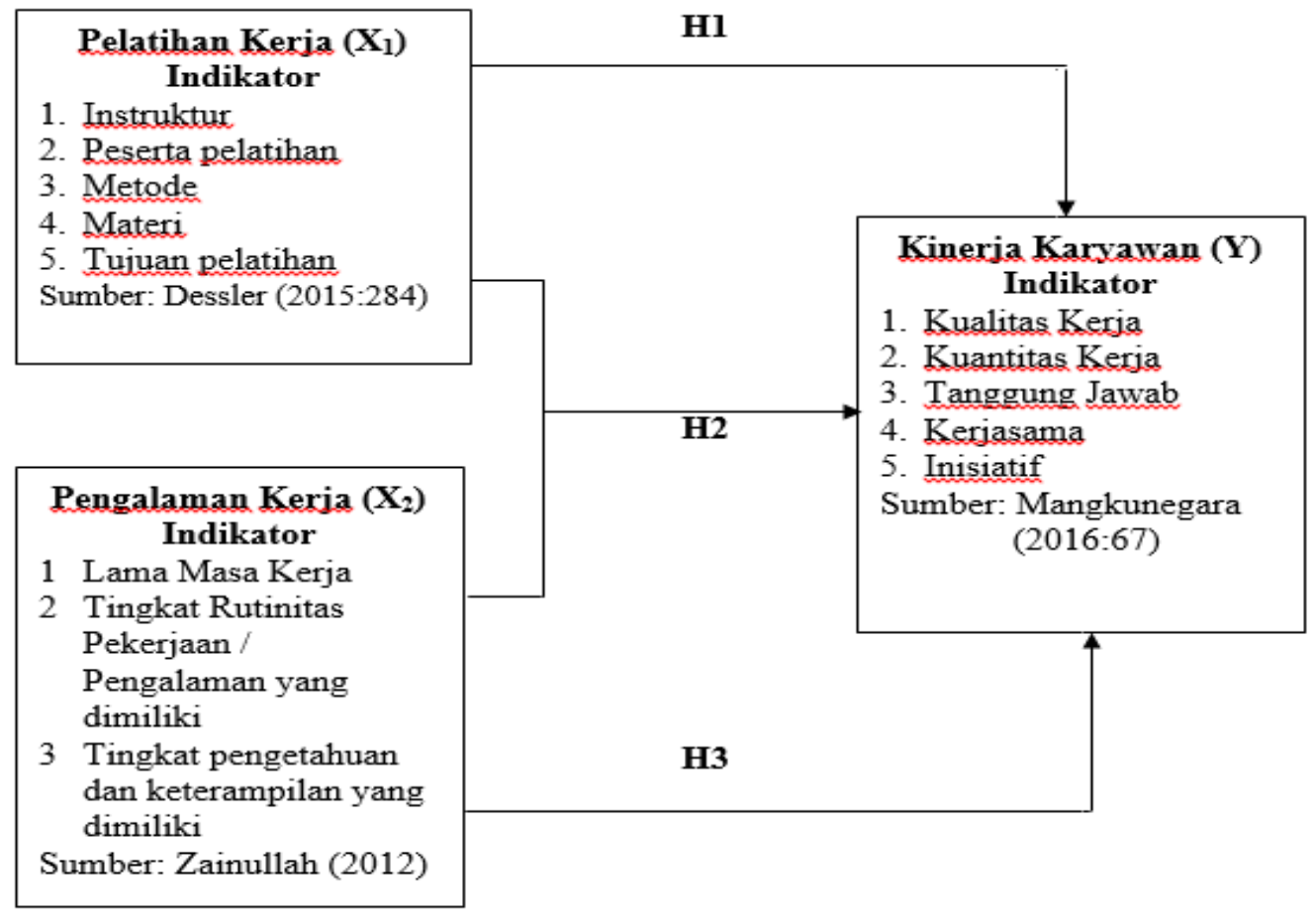

\section{Hipotesis}

Gambar 1. Kerangka Berpikir

Menurut Sugiyono (2017) "hipotesis merupakan jawaban sementara terhadap rumusan masalah penelitian, dimana rumusan masalah dinyatakan dalam bentuk kalimat pernyataan. Dikatakan sementara, karena jawaban yang diberikan baru berdasarkan teori yang relevan, belum didasarkan pada fakta-fakta empiris yang diperoleh memalui pengumpulan data atau kuesioner".

$\mathrm{H} 1$ = Pelatihan kerja berpengaruh positif dan signifikan terhadap kinerja karyawan

$\mathrm{H} 2$ = Pengalaman kerja berpengaruh positif dan signifikan terhadap kinerja karyawan

$\mathrm{H} 3$ = Pelatihan kerja dan pengalaman kerja secara simultan berpengaruh positif dan signifikan terhadap kinerja karyawan 


\section{Metode Penelitian}

Jenis penelitian ini adalah penelitian kuantitatif. Menurut Sugiyono (2017:13) "Metode penelitian kuantitatif dapat diartikan sebagai metode penelitian yang berlandaskan pada filsafat positivisme, digunakan untuk meneliti pada populasi atau sampel tertentu, teknik pengambilan sampel pada umumnya dilakukan secara random, pengumpulan data menggunakan instrumen penelitian, analisis data bersifat kuantitatif/statistik dengan tujuan untuk menguji hipotesis yang telah ditetapkan." Sedangkan metode yang digunakan menggunakan metode Asosiatif, menurut Sugiyono (2017:44), "penelitian Asosiatif bertujuan untuk mengetahui pengaruh atau hubungan antara dua variabel lebih.

Populasi dari penelitian ini adalah seluruh karyawan PT. ISS Indonesia yang berjumlah 150 karyawan. Teknik sampling yang digunakan dalam penelitian ini sampling jenuh. Lebih lanjut Sugiyono (2017:20) menjelaskan sampling Jenuh adalah teknik penentuan sampel bila semua anggota populasi digunakan sebagai sampel. Pada pembahasan populasi dan sampel diatas penulis menyimpulkan, untuk sampel dalam penelitian ini menggunakan sampling jenuh yaitu jumlah keseluruhan PT. ISS Indonesia yang berjumlah 150 karyawan.

\section{Hasil Penelitian dan Pembahasan Uji Regresi Linier Sederhana}

Menurut Supardi (2013:156), "analisis regresi linier sederhana digunakan untuk mengetahui pola variabel dependent (kriteria) dapat dipredisikan melalui variabel independent (prediktor)".

Tabel 1. Regresi Linier Sederhana $X_{1}$ Terhadap Y

\begin{tabular}{|c|c|c|c|c|c|c|}
\hline \multirow{2}{*}{ Model } & \multicolumn{2}{|c|}{ Unstandardized Coefficients } & $\begin{array}{c}\text { Standardized } \\
\text { Coefficients }\end{array}$ & \multirow{2}{*}{ t } & \multirow{2}{*}{ Sig. } \\
\cline { 3 - 5 } & B & Std. Error & Beta & & \\
\hline \multirow{2}{*}{1} & (Constant) & 23.890 & 1.273 & & 18.773 & .000 \\
\cline { 2 - 7 } & Pelatihan & .422 & .033 & .721 & 12.659 & .000 \\
\hline
\end{tabular}

a. Dependent Variable: Kinerja

Sumber: Hasil Olahan Data SPSS 25 (2021)

Berdasarkan hasil perhitungan tersebut maka dapat diperoleh persamaan regresi linier sederhana sebagai berikut: $\mathbf{Y}=\mathbf{2 3 , 8 9 0 + 0 , 4 2 2 X _ { 1 }}$ Artinya nilai (a) atau konstanta sebesar 23,890 nilai ini menunjukan bahwa pada saat pelatihan kerja $\left(\mathrm{X}_{1}\right)$ bernilai nol atau tidak meningkat, maka kinerja karyawan (Y) akan tetap bernilai 23,890. Koefisien regresi nilai (b) sebesar 0,422 (positif) yaitu menunjukkan pengaruh yang searah yang artinya setiap kenaikan pelatihan kerja sebesar satu satuan maka akan meningkatkan kinerja karyawan sebesar 0,422 satuan.

Tabel 2. Regresi Linier Sederhana $X_{2}$ Terhadap $Y$

\begin{tabular}{|c|c|c|c|c|c|c|}
\hline \multirow{2}{*}{ Model } & \multicolumn{2}{|c|}{ Unstandardized Coefficients } & $\begin{array}{c}\text { Standardized } \\
\text { Coefficients }\end{array}$ & \multirow{2}{*}{$\mathrm{t}$} & \multirow{2}{*}{ Sig. } \\
\cline { 3 - 5 } & (Constant) & 25.944 & 1.605 & & & \\
\hline \multirow{2}{*}{1} & B & .611 & .071 & .579 & 8.630 & .000 \\
\cline { 2 - 6 } & Pengalaman & .6161 & .000 \\
\hline
\end{tabular}

a. Dependent Variable: Kinerja

Sumber: Hasil Olahan Data SPSS 25 (2021)

Berdasarkan hasil perhitungan tersebut maka dapat diperoleh persamaan regresi linier sederhana sebagai berikut: $\mathbf{Y}=\mathbf{2 5 , 9 4 4 + 0 , 6 1 1} \mathbf{X}_{\mathbf{2}}$ Artinya nilai (a) atau konstanta sebesar 25,944 nilai ini menunjukan bahwa pada saat pengalaman kerja $\left(\mathrm{X}_{2}\right)$ bernilai nol atau tidak meningkat, maka kinerja karyawan (Y) akan tetap bernilai 25,944. Koefisien regresi nilai (b) sebesar 0,611 (positif) yaitu menunjukkan pengaruh yang searah yang artinya setiap kenaikan pengalaman kerja sebesar satu satuan maka akan meningkatkan kinerja karyawan sebesar 0,611 satuan. 


\section{Uji Regresi Linier Berganda}

Menurut Sugiyono (2015:277), "analisis regresi linier berganda bermaksud meramalkan bagaimana keadaan (naik turunnya) variabel dependen, bila dua atau lebih variabel independen sebagai faktor prediktor dimanipulasi (dinaik turunkan nilainya).

\section{Tabel 3. Regresi Linier Berganda}

\begin{tabular}{|c|c|c|c|c|c|c|}
\hline & \multirow[t]{2}{*}{ Model } & \multicolumn{2}{|c|}{ Unstandardized Coefficients } & $\begin{array}{l}\text { Standardized } \\
\text { Coefficients }\end{array}$ & \multirow[t]{2}{*}{$\mathrm{t}$} & \multirow[t]{2}{*}{ Sig. } \\
\hline & & $B$ & Std. Error & Beta & & \\
\hline \multirow[t]{3}{*}{1} & (Constant) & 21.468 & 1.417 & & 15.148 & .000 \\
\hline & \begin{tabular}{|l|} 
Pelatihan \\
\end{tabular} & .341 & .040 & .583 & 8.543 & .000 \\
\hline & Pengalaman & .247 & .072 & .234 & 3.430 & .001 \\
\hline
\end{tabular}

a. Dependent Variable: Kinerja

Sumber: Hasil Olahan Data SPSS 25 (2021)

Berdasarkan hasil perhitungan tersebut maka dapat diperoleh persamaan regresi linier berganda sebagai berikut:

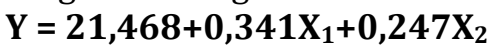

1) Konstanta sebesar 21,468 artinya jika variabel pelatihan kerja dan variabel pengalaman kerja, bernilai nol atau tidak meningkat maka kinerja karyawan akan tetap bernilai sebesar 21,468 .

2) Nilai regresi $0,341 X_{1}$ (positif) artinya apabila variabel pelatihan kerja $\left(X_{1}\right)$ meningkat sebesar 1 satuan dengan asumsi variabel pengalaman kerja $\left(\mathrm{X}_{2}\right)$ dalam keadaan tetap, maka kinerja karyawan $(\mathrm{Y})$ akan meningkat sebesar 0,341 satuan.

3) Nilai regresi $0,247 \mathrm{X}_{2}$ (positif) artinya apabila variabel pengalaman kerja $\left(\mathrm{X}_{2}\right)$ meningkat sebesar 1 satuan, dengan asumsi variabel pelatihan kerja $\left(\mathrm{X}_{1}\right)$ tetap, maka kinerja karyawan (Y) akan meningkat sebesar 0,247 satuan.

\section{Uji Koefisien Determinasi}

Uji Koefisien determinasi digunakan untuk mengetahui seberapa besar kontribusi variabel independen terhadap variabel dependen dan hasilnya dalam bentuk persentase (\%).

Tabel 4. Koefisien Determinasi $\left(\mathrm{X}_{1}\right)$ Terhadap (Y) Model Summary

\begin{tabular}{|c|c|c|c|c|}
\hline Model & $\mathrm{R}$ & $\mathrm{R}$ Square & $\begin{array}{c}\text { Adjusted R } \\
\text { Square }\end{array}$ & $\begin{array}{c}\text { Std. Error of the } \\
\text { Estimate }\end{array}$ \\
\hline 1 & $.721^{\mathrm{a}}$ & 0,520 & 0,517 & 4,83109 \\
\hline
\end{tabular}

a. Predictors: (Constant), Pelatihan

Sumber: Hasil Olahan Data SPSS 25 (2021)

Berdasarkan tabel 4 dapat diketahui bahwa besarnya nilai koefisien determinasi ditunjukkan oleh nilai $R$ Square sebesar 0,520 yang artinya variabel pelatihan kerja $\left(\mathrm{X}_{1}\right)$ memberikan kontribusi terhadap variabel kinerja karyawan (Y) sebesar 52\%, sedangkan sisanya sebesar $48 \%$ di sebabkan oleh variabel lain yang tidak diteliti dalam penelitian ini.

Tabel 5. Koefisien Determinasi $\left(\mathrm{X}_{2}\right)$ Terhadap (Y) Model Summary

\begin{tabular}{|c|c|c|c|c|}
\hline Model & $\mathrm{R}$ & R Square & $\begin{array}{c}\text { Adjusted R } \\
\text { Square }\end{array}$ & $\begin{array}{c}\text { Std. Error of the } \\
\text { Estimate }\end{array}$ \\
\hline 1 & $.579^{a}$ & 0,335 & 0,330 & 5,68673 \\
\hline
\end{tabular}

a. Predictors: (Constant), Pengalaman

Sumber: Hasil Olahan Data SPSS 25 (2021) 
Berdasarkan tabel 5 dapat diketahui bahwa besarnya nilai koefisien determinasi ditunjukkan oleh nilai $R$ Square sebesar 0,335 yang artinya variabel pengalaman kerja $\left(\mathrm{X}_{2}\right)$ memberikan kontribusi terhadap variabel kinerja karyawan $(\mathrm{Y})$ sebesar 33,5\%, sedangkan sisanya sebesar $66,5 \%$ di sebabkan oleh variabel lain yang tidak diteliti dalam penelitian ini.

Tabel 6 Koefisien Determinasi Simultan Model Summaryb

\begin{tabular}{|c|c|c|c|c|}
\hline Model & $\mathrm{R}$ & R Square & $\begin{array}{c}\text { Adjusted R } \\
\text { Square }\end{array}$ & $\begin{array}{c}\text { Std. Error of the } \\
\text { Estimate }\end{array}$ \\
\hline 1 & $.745^{\mathrm{a}}$ & 0,555 & 0,549 & 4,66448 \\
\hline
\end{tabular}

a. Predictors: (Constant), Pengalaman, Pelatihan

b. Dependent Variable: Kinerja

Sumber: Hasil Olahan Data SPSS 25 (2021)

Berdasarkan tabel 6 dapat diketahui bahwa besarnya nilai koefisien determinasi ditunjukkan oleh nilai $R$ Square sebesar 0,555 yang artinya secara simultan variabel pelatihan kerja $\left(\mathrm{X}_{1}\right)$ dan variabel pengalaman kerja $\left(\mathrm{X}_{2}\right)$ memberikan kontribusi terhadap variabel kinerja karyawan (Y) sebesar 55,5\%, sedangkan sisanya sebesar 44,5\% di sebabkan oleh variabel lain yang tidak diteliti dalam penelitian ini.

\section{Uji Hipotesis \\ Uji Hipotesis Parsial}

Tabel 7 Uji t Parsial ( $\mathrm{X}_{1}$ ) Terhadap (Y)

\begin{tabular}{|c|c|c|c|c|c|c|}
\hline \multirow{2}{*}{ Model } & \multicolumn{2}{|c|}{ Unstandardized Coefficients } & $\begin{array}{c}\text { Standardized } \\
\text { Coefficients }\end{array}$ & \multirow{2}{*}{$\mathrm{t}$} & \multirow{2}{*}{ Sig. } \\
\cline { 3 - 5 } & B & Std. Error & Beta & & \\
\hline \multirow{2}{*}{1} & (Constant) & 23.890 & 1.273 & & 18.773 & .000 \\
\cline { 2 - 7 } & Pelatihan & .422 & .033 & .721 & 12.659 & .000 \\
\hline
\end{tabular}

a. Dependent Variable: Kinerja

Sumber: Hasil Olahan Data SPSS 25 (2021)

Berdasarkan tabel 4.25, dapat diketahui bahwa variabel pelatihan kerja $\left(\mathrm{X}_{1}\right)$ memiliki nilai $t_{\text {hitung }} 12,659>t_{\text {tabel }} 1,976$ dengan tingkat signifikan 0,000 $<0,05$ maka H0 ditolak dan Ha diterima menandakan bahwa Terdapat pengaruh positif dan signifikan antara pelatihan kerja terhadap kinerja karyawan Pada PT.ISS Indonesia.

Tabel 8 Uji t Parsial $\left(\mathrm{X}_{2}\right)$ Terhadap (Y)

\begin{tabular}{|c|c|c|c|c|c|c|}
\hline \multirow{2}{*}{ Model } & \multicolumn{2}{|c|}{ Unstandardized Coefficients } & $\begin{array}{c}\text { Standardized } \\
\text { Coefficients }\end{array}$ & \multirow{2}{*}{$\mathrm{t}$} & \multirow{2}{*}{ Sig. } \\
\cline { 3 - 5 } \multicolumn{2}{|c|}{} & B & Std. Error & Beta & & \\
\hline \multirow{2}{*}{1} & Constant) & 25.944 & 1.605 & & 16.161 & .000 \\
\cline { 2 - 7 } & Pengalaman & .611 & .071 & .579 & 8.630 & .000 \\
\hline
\end{tabular}

a. Dependent Variable: Kinerja

Sumber: Hasil Olahan Data SPSS 25 (2021)

Berdasarkan tabel 4.26, dapat diketahui bahwa variabel pelatihan kerja $\left(\mathrm{X}_{2}\right)$ memiliki nilai $t_{\text {hitung }} 8,6630>t_{\text {tabel }} 1,976$ dengan tingkat signifikan 0,000 $<0,05$ maka H0 ditolak dan Ha diterima menandakan bahwa Terdapat pengaruh positif dan signifikan antara pengalaman kerja terhadap kinerja karyawan Pada PT. ISS Indonesia.

\section{Uji Hipotesis Simultan}

Pengujian secara keseluruhan digunakan untuk mengetahui apakah ada pengaruh secara bersama-sama (simultan) dari variabel pelatihan kerja dan pengalaman kerja terhadap 
kinerja karyawan. Pengujian ini dilakukan menggunakan distribusi F dengan membandingkan anatara nilai $\mathrm{F}_{\text {hitung }}$ dengan nilai $\mathrm{F}_{\text {tabel }}$.

Tabel 9 Uji F Fitung Simultan

ANOVAa $^{\mathrm{a}}$

\begin{tabular}{|l|l|r|r|r|r|c|}
\hline \multicolumn{2}{|c|}{ Model } & $\begin{array}{c}\text { Sum of } \\
\text { Squares }\end{array}$ & \multicolumn{1}{c|}{ df } & $\begin{array}{c}\text { Mean } \\
\text { Square }\end{array}$ & F & \multicolumn{1}{c|}{ Sig. } \\
\hline \multirow{2}{*}{1} & Regression & 3996,265 & 2 & 1998,133 & 91,837 & $.000^{\mathrm{b}}$ \\
\cline { 2 - 7 } & Residual & 3198,328 & 147 & 21,757 & & \\
\cline { 2 - 7 } & Total & 7194,593 & 149 & & & \\
\hline
\end{tabular}

a. Dependent Variable: Kinerja

b. Predictors: (Constant), Pengalaman , Pelatihan

Sumber: Hasil Olahan Data SPSS 25 (2021)

Berdasarkan tabel 4.27 diperoleh nilai $\mathrm{F}_{\text {hitung }} 91,837>\mathrm{F}_{\text {tabel }}$ 3,905 dengan tingkat siginifikan 0,000 $<0,05$ dengan demikian Ho ditolak dan Ha diterima, artinya secara simultan terdapat pengaruh yang positif dan signifikan antara pelatihan kerja dan pengalaman kerja terhadap kinerja karyawan Pada PT.ISS Indonesia.

\section{Kesimpulan}

Berdasarkan hasil penelitian yang telah diuraikan maka kesimpulan dalam penelitian ini adalah sebagai berikut: 1) Terdapat pengaruh positif dan signifikan pelatihan kerja terhadap kinerja karyawan pada PT. ISS Indonesia. 2) Terdapat pengaruh positif dan signifikan pengalaman kerja terhadap kinerja karyawan pada PT. ISS Indonesia. 3) Terdapat pengaruh positif dan signifikan pelatihan kerja dan pengalaman kerja secara simultan terhadap kinerja karyawan pada PT. ISS Indonesia.

\section{Daftar Pustaka}

Dessler, G. (2015). Manajemen Sumber Daya Manusia. Jakarta: Salemba Empat.

Edison, E. (2016). Manajemen Sumber Daya. Manusia. Bandung: Alfabeta.

Ghozali, I. (2016). Aplikasi Analisis Multivariete Dengan Program. IBM SPSS 23 (Edisi 8). Cetakan ke VIII. Semarang : Badan Penerbit Universitas Diponegoro.

Gomes, F.C. (2016). Manajemen Sumber Daya Manusia. Jakarta: Andi Offset.

Hafeez, U., \& Akbar, W. 2015. Impact of Training on Employee's Performance: Evidence from Pharmaceutical Companies in Karachi, Pakistan. Business. Perusahaan Farmasi.

Hasibuan, M.S.P. (2016). Manajemen Sumber Daya Manusia. Edisi. Revisi. Jakarta: Penerbit PT Bumi Aksara.

Kosdianti, L., \& Sunardi, D. (2021). Pengaruh Pelatihan Terhadap Kinerja Karyawan Pada PT. Satria Piranti Perkasa Di Kota Tangerang. Jurnal Arastirma, 1(1), 141-150. Https://Doi.Org/10.32493/Arastirma.V1i1.10070

Luffi, M., Agrasadya, A., \& Apriansyah, M. (2021). Pengaruh Pelatihan Dan Kompensasi Terhadap Kinerja Karyawan Pada PT. G4S Security Service Jakarta (Studi Kasus Pada Karyawan Security Projek PT HM Sampoerna Tbk Di Jakarta). Jurnal Arastirma, 1(1), 93-105. Https://Doi.Org/10.32493/Arastirma.V1i1.10066

Munda, A. O., \& Yuniawan, A. (2018). Pengaruh Work Family Conflict Dan Ambiguitas Peran Terhadap Intention To Quit Dengan Stres Kerja Sebagai Variabel Intervening (Studi Pada Hotel Grand Edge Semarang). Diponegoro Journal Of Management, 6(96), $1-12$. 
Mangkunegara, A.A.A.P. (2016). Manajemen Sumber Daya Manusia. Perusahaan. Bandung : PT. Remaja Rosdakarya.

Marwansyah. (2016). Manajemen Sumber Daya Manusia. Bandung: Alfabeta.

Robert \& Bacal. (2016). Performance Management. Jakarta: Gramedia Pustaka Utama.

Sugiyono. (2017). Metode Penelitian Kuantitatif, Kualitatif, dan R\&D. Bandung: Alfabeta.

Supardi. (2013) Aplikasi Statistika dalam Penelitian Konsep Statistika yang Lebih. Komprehensif. Jakarta: Change Publication.

Sutrisno, E. (2016), Manajemen Sumber Daya Manusia, Jakarta: Kencana Prenada. Media Group.

Trijoko. (2008). Ilmu Budaya Dasar. Jakarta: PT Rineka Cipta

Widodo, E.S. (2015). Manajemen Pengembangan Sumber Daya Manusia. Yogyakarta: Pustaka Pelajar.

Yani, A. N. R., Susilo, H., \& Ruhana, I. (2016). Pengaruh Penempatan Karyawan Terhadap Motivasi dan Kinerja (Studi pada karyawan PT Perkebunan Nusantara X (PG Watoetoelis) Sidoarjo). Jurnal Administrasi Bisnis, 30(1), 178-185.

Zainullah, A, et. al. 2012 .PengaruhKemampuan Dan Pengalaman Kerja Terhadap Kinerja Pekerja Pelaksanaan Bekisting Pada Pekerjaan Beton. Jurnal Rekayasa Sipil. Volume 6 No.2: Jurnal Publikasi. 